\section{TANDEM ROBOTIC FCAW} WELDING

MARIAN SIGMUND

FSI VUT Brno, Faculty of Mechanical Engineering, Institute of Welding and Surface Threatment, Brno, Czech Republic

DOI: 10.17973/MMSJ.2019_06_2019002

sigmund@fme.vutbr.cz

This article describes robotic FCAW welding with using tandem torch for welding bearing parts of mobile truck crane. Follow primary objective advantages of tandem welding compared to welding with classical single wire. Mainly in light of welding speed, welding productivity with reference to resulting weld quality. In article isfirstly described comparison of both robotic welding cells and also technologies of production, including technological welding processes for single wire and already mentionedtandem wire robotic welding cell. Secondaryare described modernized robotic welding cell used benefits from tandemtorch with laser off-line sensor servant to searching weld position. Part of tandem robotic welding cell is as well two axis welding positioner. In light of used welding technology we speak about shielded arc welding process with metal flux cored wire.

KEYWORDS

FCAW welding - welding method 138 (is shielded arc welding in active gases with metal flux cored wire), tandemrobot welding, off-line laser senzor.

\section{INTRODUCTION}

Raising welding productivity with keeping required weld quality is actual and discussed topic in all branches of engineering industry, especially in automotive industry. For these kind of industry were classical manual welding, mainly for reasons higher welding speed and shorter welding times, quite replaced by robotic welding. As well by the robotic welding methods (how conventional so also unconventional named hybrid) researchers wants to find ways and means how to raise welding affectivity and welding productivity. One of possibility how raise welding speed is used metal flux cored wires instead welding with solid wires. Other possibility is replace current single wire torch to twin wires better to tandem torch thereby raise the productivity as far as two times. Both possibilities in comparison of single wire and tandem robotic welding cell will be described in this experiment.

\section{WELDED PART}

Welded part on Figure 1 is part so - called hydraulic hands, be specific acts to bearing part of mobile crane pillar. Pillar stay most often on truck carriage. Be placed behind bathing-machine of mobile truck crane and primary be instrumental to loading unloading and manipulation with supply. Lower part of pillar is casting on that is of already ready edged surface for bearing and milled slots forging gear design servant to turning of mobile truck crane. Other components of bearing part of mobile crane pillar are manufacture from semi products acc. Table 1, that are further cutted by laser and consequently welded. Whole technological process of production bearing part of mobile crane pillar is displayed on diagram on Figure 2.

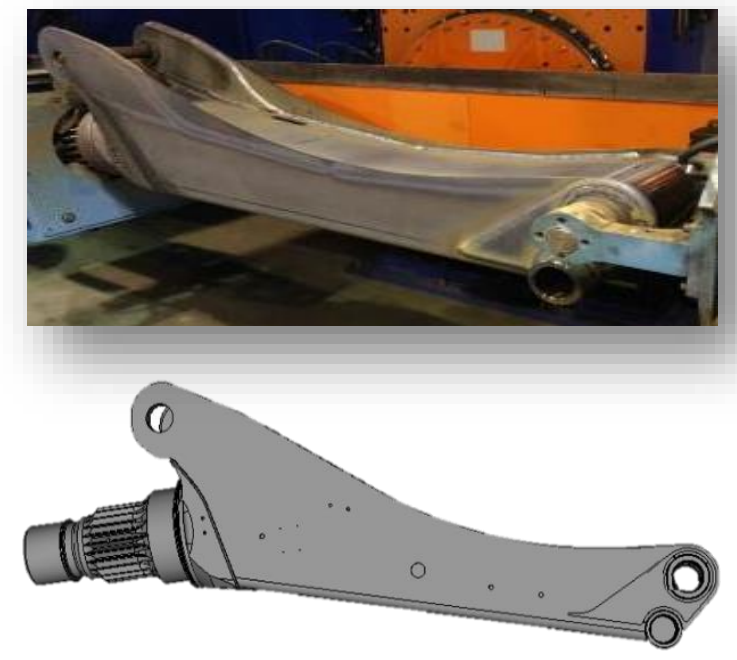

Figure 1.Bearing part of mobile crane pillar

\begin{tabular}{|l|l|l|}
\hline \multicolumn{1}{|c}{ Name } & \multicolumn{1}{c|}{ Semi Product } & \multicolumn{1}{c|}{ Base Material } \\
\hline Plug & $\begin{array}{l}\text { Tube } \\
114,3 \times 17,5 \times 6000\end{array}$ & $\begin{array}{l}\text { Casting } \\
\text { S355J2H }\end{array}$ \\
\hline Tube & $\begin{array}{l}\text { Tube } \\
114,3 \times 17,5 \times 6000\end{array}$ & 42CrMo4+QT \\
\hline Tube & $\begin{array}{l}\text { Plate } \\
8 \times 1800 \times 2000\end{array}$ & WELDOX700E \\
\hline Plate & $\begin{array}{l}\text { Plate } \\
8 \times 1800 \times 2000\end{array}$ & WELDOX700E \\
\hline Rib & $\begin{array}{l}\text { Plate } \\
8 \times 1500 \times 2000\end{array}$ & DOMEX700M \\
\hline Pillar plate & $\begin{array}{l}\text { Plate } \\
25 \times 1250 \times 2500\end{array}$ & WELDOX960E \\
\hline Reinforcement & $\begin{array}{l}\text { Plate } \\
8 \times 1800 \times 2000\end{array}$ & WELDOX700E \\
\hline Facing plate & $\begin{array}{l}\text { Plate } \\
25 \times 1250 \times 2500\end{array}$ & WELDOX960E \\
\hline Reinforcement &
\end{tabular}

Table 1. Semi products and base materials bearing part of mobile crane pillar 


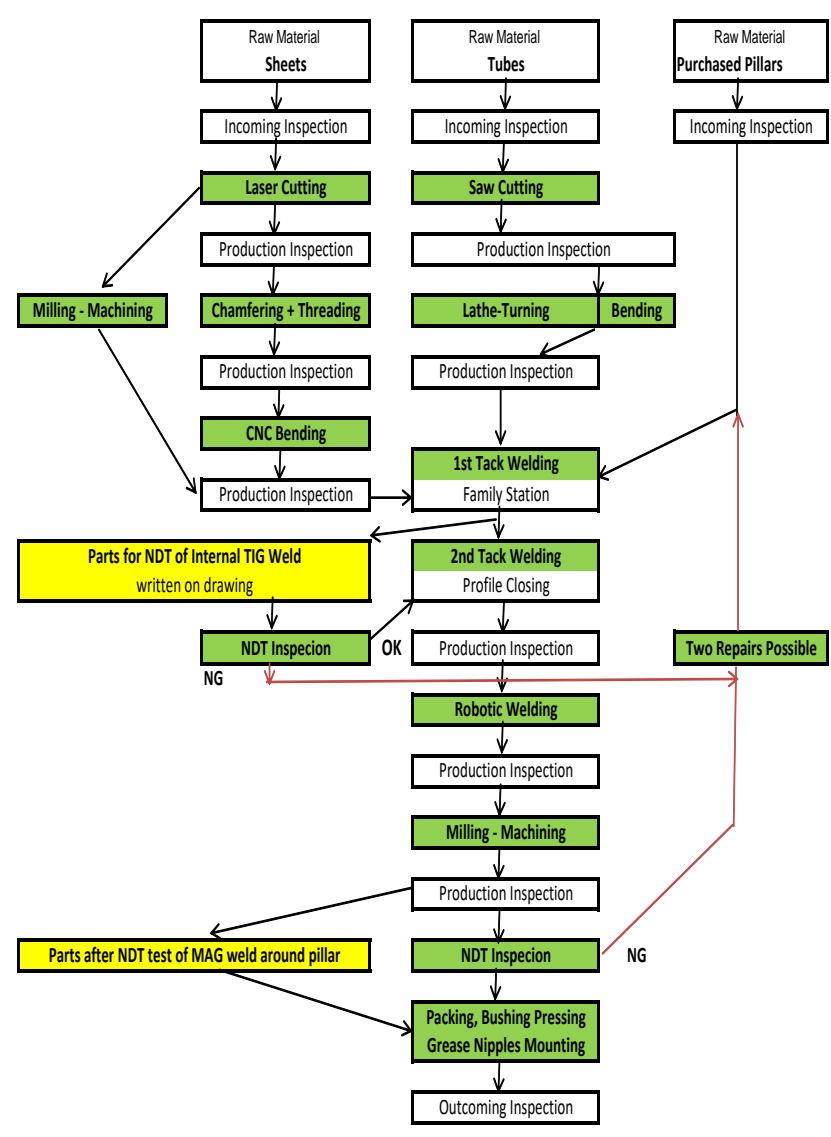

Figure 2.Diagram of whole technological process production of bearing part mobile crane pillar

\subsection{Robotic welding cells}

First robotic welding cell was equipped by older welding robot IGM with classical welding head for welding with single wire used two rotary positioners. Welded part turns in positioners. Robotic welding cell IGM is displaced on Figure 3. Second robotic welding cell was equipped by welding robot CLOOS with two welding heads with tandem torchesmake - up used two axis positioner with more degrees of moving. Welding robot CLOOS be invested with off-line laser senzor to more accurately guidance of welding wire to welding spot and verification of all welding. Roboticwelding cell CLOOS inclusive tandem torch is displaced on Figure 4.

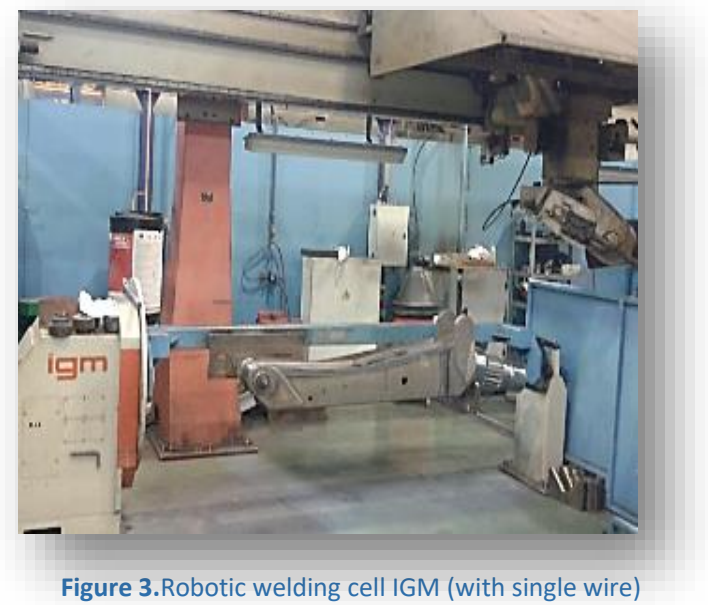

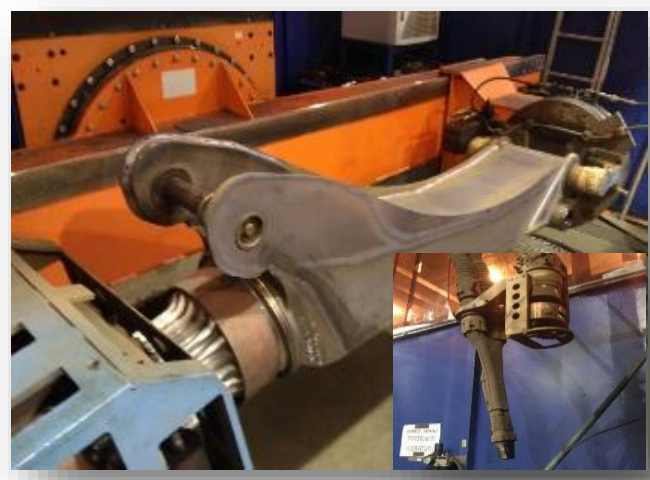

Figure 4.Robotic welding cell CLOOS (with tandem torch)

\subsection{Welding procedure specifications}

Individual welding procedure specification (WPS) for specific robotic welding cells are mentioned on so - called welding or WPS maps. To specific welds are associated specific welding procedure specification. On Figure 5 are displayed WPS maps for robotic welding cell IGM. Welds marked WPS A belongs to welding pin and bearing part and is welded manually by FCAW welding technique. Welds marked WPS B are welded by FCAW welding technique on robot with single wire technology.
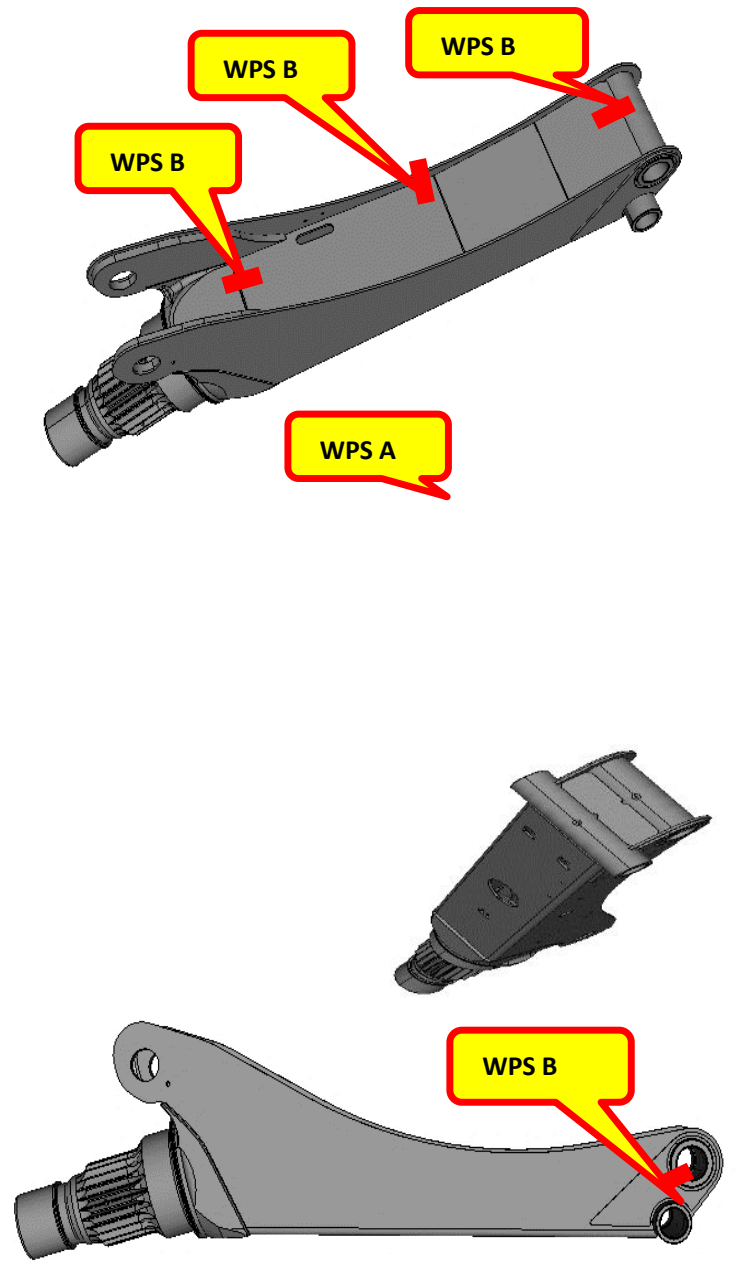

Figure 5.WPS maps for robotic welding cell IGM (with single wire)

On Figure 6 are displayed WPS map for robotic welding cell CLOOS. Welds marked WPS A be like each other as in the case 
for welding cell IGM provided by manual FCAW welding technology. Welds marked WPS B are roboticFCAW welds welded with single wire torch, cause these welds are so short and in restricted space, where will be not fully used benefits of tandem torch. Position weld marked WPS C tandem is welded by robot FCAW welding technique with tandem torch.
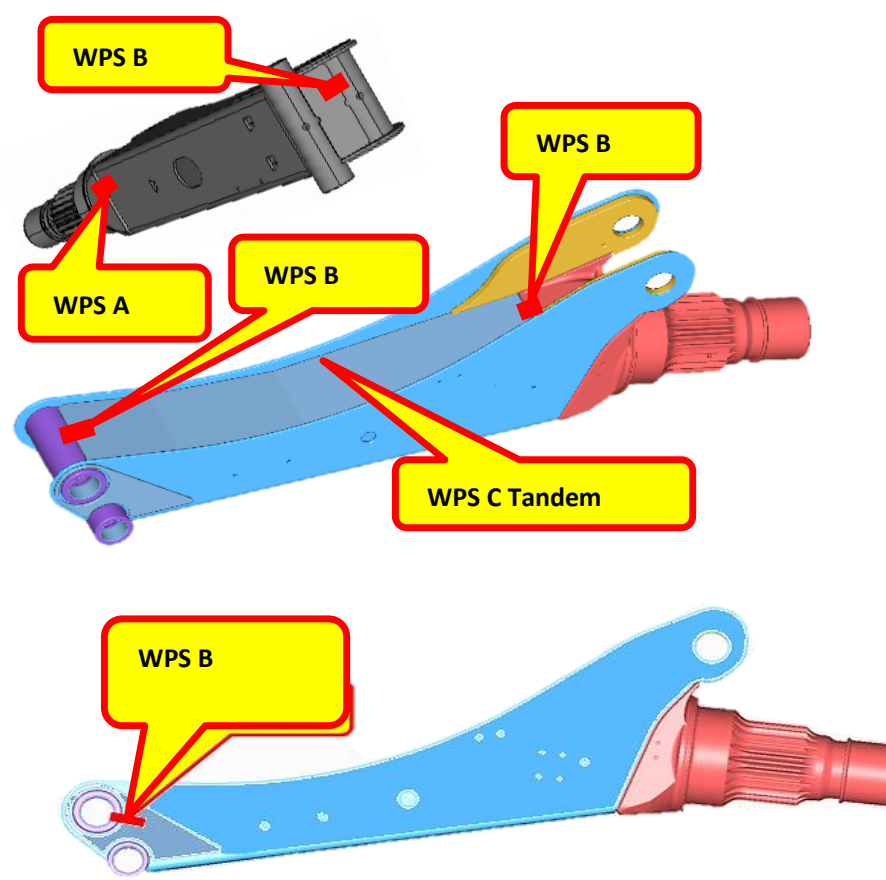

Figure 6.WPS maps for robotic welding cell CLOOS (with tandem torch)

Individual variables and welding parameters from each other welding procedure specifications are displayed in following tables. In Table 2 are common variables for all welding procedure specifications. In Table 3 are welding parameters for manual FCAW welding WPS A type. In Table 4 are welding parameters for robotic FCAW welding WPS B type - welded with single wire. In Table 5 are welding parameters for FCAW welding WPS C type - welded with tandem torch.

\begin{tabular}{l|l|l|}
\multicolumn{3}{|c|}{ WPS A (manual)acc. EN ISO 15609-1 } \\
$\begin{array}{l}\text { WPS B (robotized with single wire)acc. EN ISO 15609-1 } \\
\text { WPS C (robotizedwith tandem torch)acc. EN ISO 15609-1 }\end{array}$ \\
\hline Welding Method & EN ISO 4063 & 138 \\
\hline Type of Weld & EN ISO 15614-1 & BW (Butt Weld) \\
\hline Welding Position & EN ISO 6947 & PA, PB \\
\hline Base Material & EN ISO 15608 Gr. & WELDOX700E \\
\hline No 3 & EN ISO 17632-A & T 46 3 M M2 H5 \\
\hline Filler Material & EN ISO 14175 & M21 \\
\hline Shielding Gas & & 8 mm \\
\hline Wall Thickness & Cutting, Mechanical Grinding \\
\hline Material Prep. & Sand Blasting, Mechanical Brusing \\
\hline Cleaning & & $12-15$ l/min. \\
\hline Gas Flow & & 2 layers \\
\hline No. Of Layers & & DC/+ \\
\hline Welding Current & &
\end{tabular}

\begin{tabular}{|l|l|}
\hline Stick Out & $18 \mathrm{~mm}$ \\
\hline Wire Diameter & $1,2 \mathrm{~mm}$ \\
\hline
\end{tabular}

Table 2. Common variables for all used welding procedure specifications

\begin{tabular}{|c|c|c|}
\hline \multicolumn{3}{|c|}{ WPS A (manual) acc. EN ISO 15609-1 } \\
\hline Welding Current & $\mathrm{I}=$ & $260 \mathrm{~A}$ \\
\hline Welding Voltage & $U=$ & $31,9 \mathrm{~V}$ \\
\hline Welding Speed & $v=$ & $35 \mathrm{~cm} / \mathrm{min}$. \\
\hline Heat Input & $Q=$ & $1,9 \mathrm{~kJ} / \mathrm{mm}$ \\
\hline
\end{tabular}

Table 3. Welding parameters for manual FCAW welding

\begin{tabular}{|l|l|l|}
\multicolumn{3}{|c}{ WPS B (robotized with singlewire) acc. EN ISO 15609-1 } \\
\hline Welding Current & $\mathrm{I}=$ & $332 \mathrm{~A}$ \\
\hline Welding Voltage & $\mathrm{U}=$ & $29,7 \mathrm{~V}$ \\
\hline Welding Speed & $\mathrm{V}=$ & $45 \mathrm{~cm} / \mathrm{min}$. \\
\hline Heat Input & $\mathrm{Q}=$ & $1,75 \mathrm{~kJ} / \mathrm{mm}$ \\
\hline
\end{tabular}

Table 4. Welding parameters for roboticFCAW welding with single wire

\begin{tabular}{|l|l|l|}
\multicolumn{2}{|c}{ WPS C (robotizedwith tandem torch) acc. EN ISO 15609-1 } \\
\hline Welding Current & $\mathrm{I}=$ & $250 \mathrm{~A}$ \\
\hline Welding Voltage & $\mathrm{U}=$ & $29 \mathrm{~V}$ \\
\hline Pendl & & $2,5 \mathrm{~mm}$ \\
\hline Welding Speed & $\mathrm{V}=$ & $45 \mathrm{~cm} / \mathrm{min}$. \\
\hline Heat Input & $\mathrm{Q}=$ & $1,29 \mathrm{~kJ} / \mathrm{mm}$ \\
\hline
\end{tabular}

Table 5. Welding parameters for robotic FCAW welding with tandemem torch

\subsection{Tandem welding}

Is process, when one's welding torch are placed two girders for two welding wires. Wires setting is inline or in tandem see Figure 7. First wire handling sufficient penetration and second wire makes it possible to fast fulfilment and big gaps with filler material. This setting will enable finish seam on one crossing. Root layer and also caps are welded at the same time. Welding arc is burning in one's common weld pool. Acts about two electrically separate, despite consistent processes. Regarding minimisation of the number of crossings is reduced quantity of heat input. It positively display on minimum weldment deformation. Biggest advantage consists in achievement higher welding speed. This method get past, how for thin and also for thick base materials. It is possible fully exploit possibility of high remelting output and high welding speed, especially with using metal flux cored wires. That increases usage auxiliary weld metal. Over indisputable benefits of those welding technology, find also here certain limitations. Regarding dimensional bigger welding nozzle, isn't enabled sufficient access to the different corners and small filled welds. Highest effectiveness is reached during welding long plane welds. 


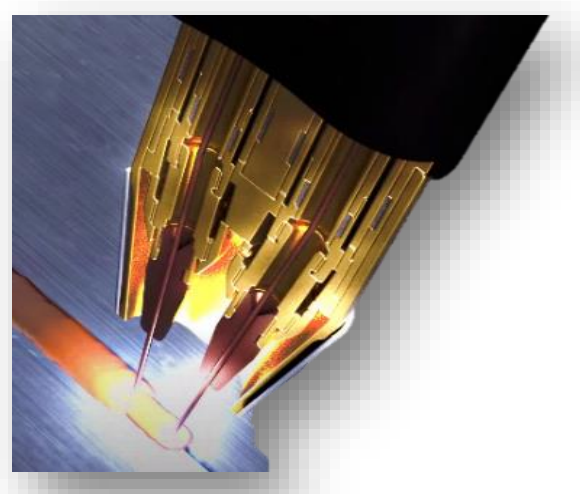

Figure 7.Wires setting in tandem torch

On Figure 8 are visible photos of welding process with shortcircuit-freeweld metal transfer in pulzed welding mode. Individual arcs are not ignition at the same time, but are synchronized and reverzed. Electronics of power source exactly designates timely ignition and both electrodesfilling up.

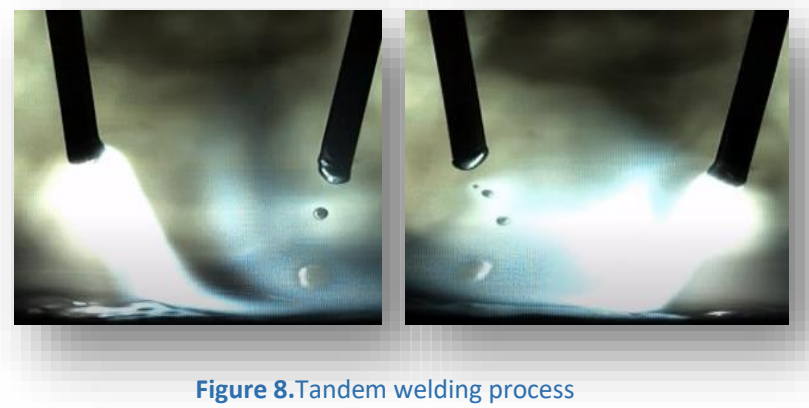

\subsection{Sensoric systems}

Gas nozzle tactile sensoris tangent searching serving to determination first welding point (start of welding), determination of contour view and weldment profile. Principle consist in starting welding nozzle at the requested start of seam (trajectory is programmed), there is a change ofcontact done by outsidewelding nozzle, welding electrode or fixed tangent sensor with welded base material. This arrangementsee in Figure 9.Robot lead torch per programmed trajectory. After sensor will touch weldment, begins in sensor pass measuring current, robot stops and this position is saved. To exact definition in $x, y, z$ coordinates is necessary touch weldment from three directions. Position of future weld is though programmed, but in reality appearance to possible parts or fixtureroughness can be softly offset. Thanks this system is minimized risk of inconveniently seam. This system was next evolutional step, when first robotized welding were performed on universal industrial robot with absence any searching and resulting seams be often placed except required trajectory. For example in case of specification of filled weld weren't welds with full penetration, but rather a to facing weld bead on horizontal or vertical part. Herewith system is possible search all base materials, which ones are electrically conductive. Benefits are absence any oblige arrangement (if isn't used stylus) and possibility programming searching straight to the welding programme.

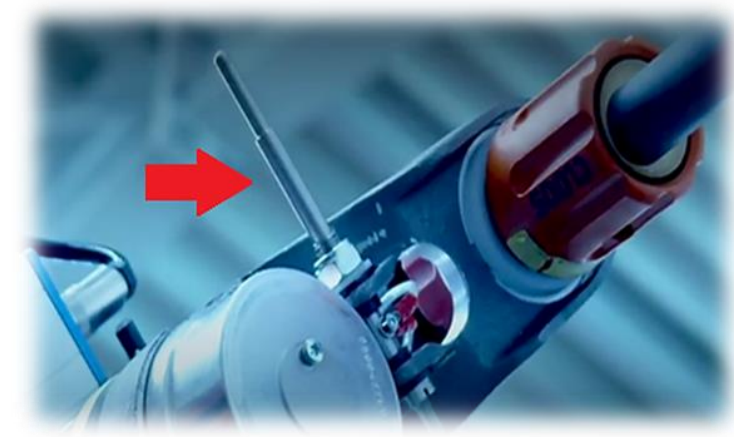

Figure 9.Gas nozzle tactile sensor

Voltaic arc sensor disserve to determination starting position of welding, but checks whether programmed trajectoryreally agrees with position of welding torch. Checking proceed during welding. If are here for example flatness variations incurred for example rising of heat input, robot recognize real contour and will carry out corresponding correction. Welding torch do oscillatory movement andsearching so sides, edges welded base material. Programmed robot revises position of torch so, to find in the middle of programmedtrajectory. Further this system revises wire stick out and torch distance from weldment. Since that the checking proceeds at the same time as welding happens to no time losing. Are not here included any oblige single parts and system used to be directly engaged on robot control unitwhere can be regulate correction sensitiveness.

Laser optical sensorsserves to determination real position of weld. In this case however is measuring proceed without contact. Principle consists in usage laser distant (without contact) sensor. Laser emissive diode with sensor photosensitive emite laser beam that reflects from surface and supplies through triangulation method voltage corresponding to distance. By sensor transversalmovement above weld is possible superfast scan signal generate and evaluate high altitude profile of measured object. Scan signal is independent to searching speed set so, to may be until searching length $1500 \mathrm{~mm}$ performed 20 pictures on $1 \mathrm{~mm}$. It follows side resolution $0,05 \mathrm{~mm}$. Searching movement is specific so, to above soughtedge run over laser beam. After it can through proceed image recognize position of weld and weld geometry, that is further processed to robot control unit. To each weld or searching movement is possible define personal weld design. Defined weld position is in advance developed on the grounds of these coordinates. In robot control unit are saved welding position. On weld geometry is possible adjust welding parameters with the view of achievement optimum welding result. Welding trajectory is saved in robot control unit and is operate by welding robot operator. Sensor beam on weldment is light beam, entraps his beam flyback andobtain needed characteristics of real position of weld geometry. Leading role consist from searchingstarts and ends of weld, recognition weldment edges, recognition piping position, measuring root gaps, verification weld disposition. This technology strong reduce demand on welding jigsand single components weldmentprecision, because will to proof offset different weld gaps. Next advantage consists in facilitation scan aluminous alloyes, highalloyedsteels or zinc coated base materials in corresponding precision, neither would had to be lowered their luminous reflectance, which isn't for optical sensors too usual. Laser sensor used to be standard combinated with voltaic arc sensor. 
Laser off-line sensor don't work during welding. Scan proceeds before welding or after welding andown process proceeds very quickly. Scaned datas are stored in robot control unit, by the help of that are optimized welding parameters to the best welding result. In case of CLOOS welding cell is sensor set in proximity welding torch on robot hand flange, it will enable reach for ultrashort searching trajectory. On Figure 10 is displayed off-line sensor with closed capping strip. Principle of scaning consists fromsensor moving to area of welding and opening capping strip blocking sensor. Happens to scaning start and endof weld in traverse direction. Capping strip closes and sensor moving away. Take place correction, welding torch moving and welding is begun. Off-line sensor isn't during welding subject to spraying which is advantage compared to online sensor.

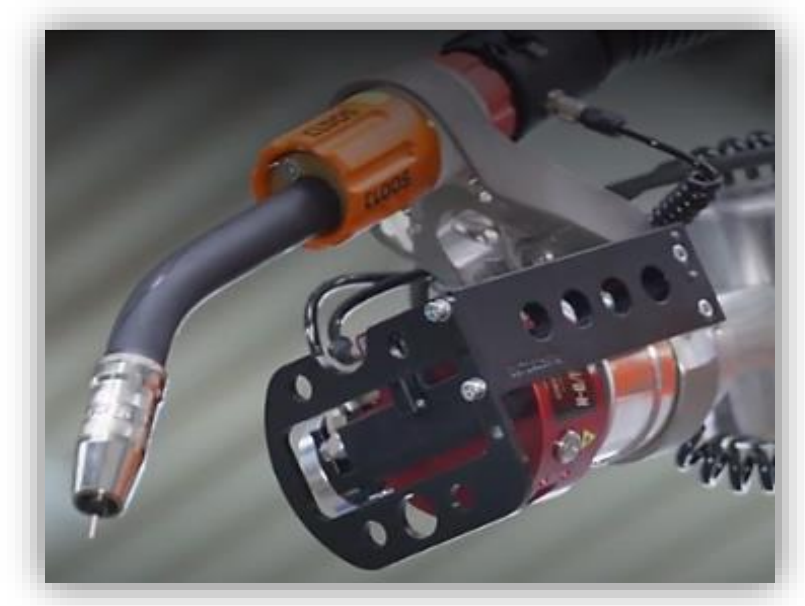

Figure 10.Laser off-line sensor

Laser on-line sensor is relatively mature searching system see in Figure 11. Measuring and correction proceed online in real time during welding. Sensor be placed at close before torch in direction his movement. Scan trajectory ready weld surface and send round data to robot control unit. This data evaluates and do optimalization of weldingproces. Manage also edit not only position of welding torch, but also welding parameters. If will come situation when flatness variations from production toleration, or established position are too large and will fail to carry out necessary correction is welding suit automatically stoped, whereby is protected production of nonconform products. This system is very proper for welding complicated parts, where isn't garranted exact fitting of required partsand isn't unequal welding gap.

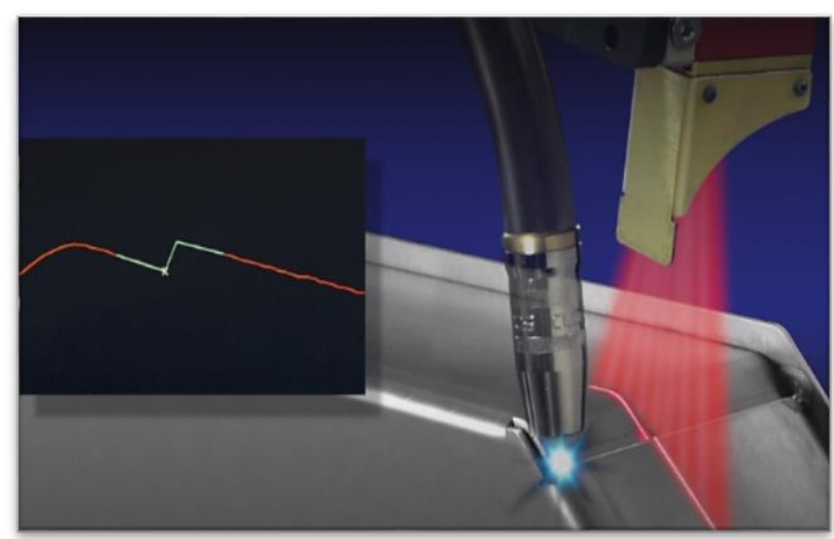

Figure11.Laser on-line sensor

\subsection{Robot welding torch cleaning}

During welding is welding torch polluted by ,spray". Spray metal is undesirable effect, when molten weld metal adhere on weldment and welding torch in practice with fine balls. Removing these fine balls used to be in many places difficult. If isnt welding torch periodically cleaned, happens to sensitive weld qualitiesdeterioration. In case manual welding is welding torch cleaned manually by welder. Robotic welding cells contain independent cleaning unit that clean welding torch by wire brush. Often also this unit includes mechanism servant to cut off welding wire, which relieves arc ignition. In case of robotic CLOOS welding cell this unit includes also equipment for application protective nozzle spray servant to minimisation spraying. Using these equipment is extend welding time(decrease necessity of frequent cleaning) and innovates removability of spraying. Number of cleaning cycles during welding is programmed by robot welding operator, according to state pollution of welding torch rising during welding. Therefore used to be number of cleaning cycles for every trajectory. On Figure 12 is shown cleaningequipment for CLOOS robotic welding cell. On the right finds position, where is clened internal part of tandem torch and is also applies separative nozzle spray. Left finds place for cleaningsingle wire torch. Up is wire brush where is clened exteriority of both torches single wire and also tandem.

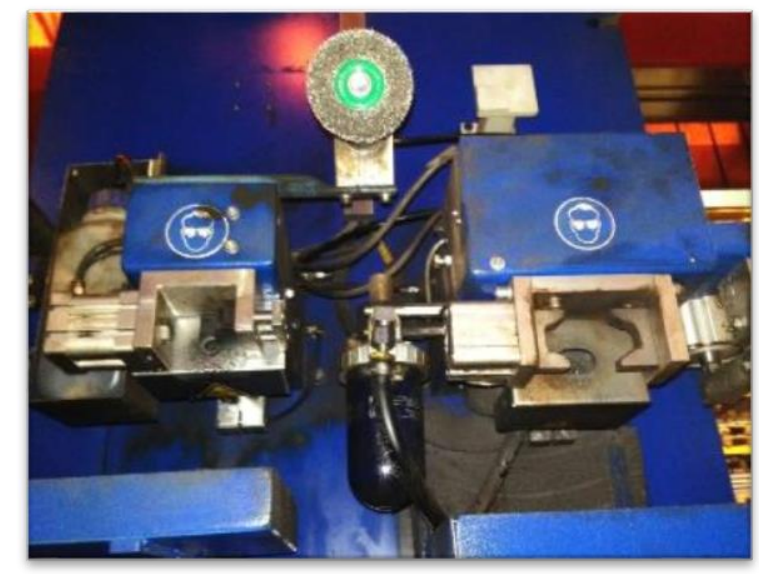

Figure 12.Cleaning equipment for CLOOS robotic welding cell

\section{NON-DESTRUCTIVE AND DESTRUCTIVE TESTS OF WELDS}

All manual and also robotic welds are checked by $100 \%$ visual exam. In addition welds, that are welded manually are checked $100 \%$ by ultrasonic or radiographic exam according customer requirements. Is concerned very important welds e.g.plug with peel plates. Manually are welded mainly for reason any access for welding robot (clamping unit forms barrier for torch). For example is necessary manually weld crossing and tacking welds. Last but not least is performed full visual check of all weldment, where will disclose and will also repair by welding all defects. Before approval whole production set are welds also checked by destructive tests. Approval is determine on the grounds penetration evaluation on macro examination. On Figure 13 areshown macrostructure examination. On first picture is shownweld produced on robotic welding cell IGM with single wire. At first look is visible sizablethermal affected zone, which is incurred by higher heat input. Regarding necessity of weld root and cap layers apart. Further is show excess run - over weld owing to gravitation, that reducestructural weld surface. On second picture finds seam welded by tandem on CLOOS robotic welding cell. Already at first look is visible higher weld 
quality, optimum horizontal and also vertical filled weld penetration and smaller thermal affected zone. Weld get past spilt thanks two-axis rotation unit, that is synchronized with welding tandem torch and compensates influence of gravitation. It incurred increasestructural weld surface about 0,46 $\mathrm{mm}$. End consumer already doesn't do othersnon-destructive weld examination. Test onlyindividual crane partsseparately, or in set namely above all on fatigue strength.
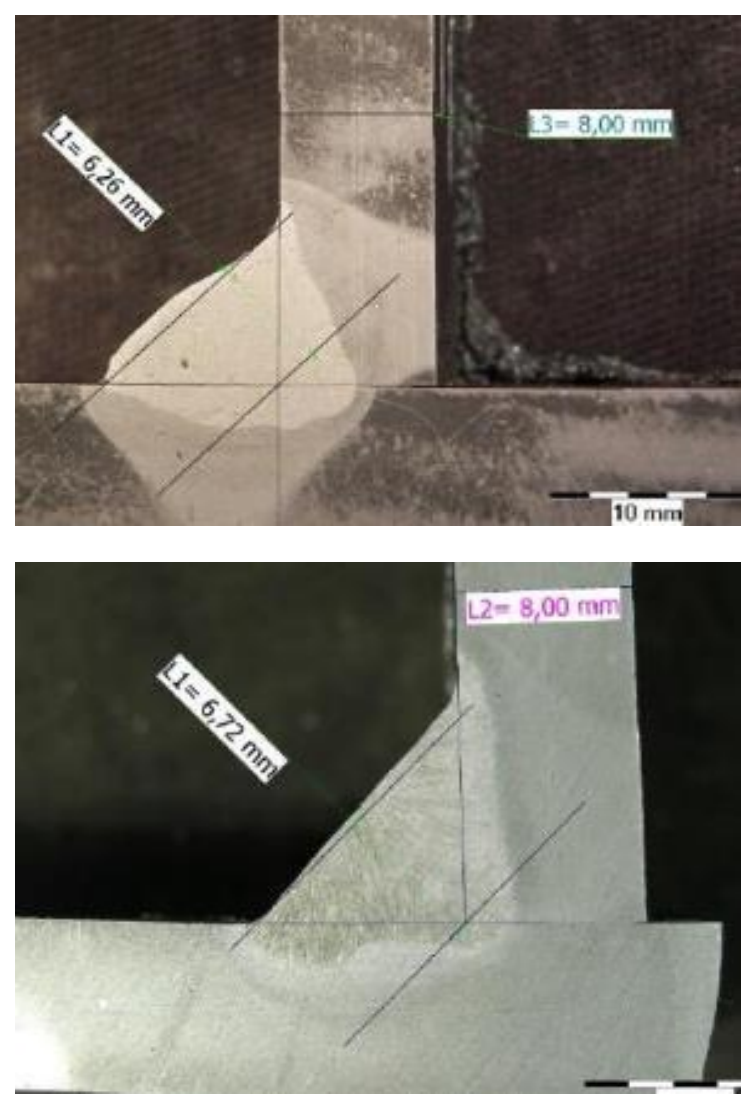

Figure 13.Macrostructure examinations, first picture - two layers welded with single wire on IGM robotic welding cell, second picture one layer welded with tandem on CLOOS robotic welding cell.

\section{EXPERIMENT EVALUATION}

Escalation welding productivity with keeping required weld qualities is very actual and discussed topic in all kinds of mechanical engineering. This statement was confirmed and therewith by this experiment. Partly by implementation metal flux cored wire for welding is possible raise welding speed as far as about $33 \%$. Plus implementation tandem welding on one layer, place two layers welding with one wire, could reduce welding time as far as by half. It all with others advantages like bigger penetration, higher weld quality, smaller heat input to the weld and smaller resulting residual stresses and deformation after welding. Unfortunately, as noted previously, so today already technologically older and longer servant robots forms welds unsatisfying in light of weld qualities, welding speed, inclusive continuous shut-downs for servicing. Therefore be necessary in all robotic services modernizing for example by using hybrid welding systems. Application of hybrid welding systems is considerably money wise. Therefore be necessary consider as well modernizing conventional classical robotic welding cells for example with using tandem or twin wire torches and off-line laser sensor and self-cleaning equipment on welding torch. Here was achieved requisite results described in this experiment.
In cooperative company will next year modernize also two more older IGM welding cell. Intended to welded posts will gradual replaced by CLOOS welding robots. Is however necessary get in that CLOOS welding robot with tandem torch welds not only for crane pillars, but also for other weldments. So to achieved full usage. Purpose is replace all types of robotic welds welded on two layers with one wire, gradual welded on one layer by tandem.conclusions

On the grounds of experiment be understood verify profitability ofnew modernized robotic CLOOS welding cell. On mobile rotary crane pillar was finallywelded 13,34 metres of welds, from that 3,6 metres of welds was welded by tandem torch. To one pillar was consumed $3,76 \mathrm{~kg}$ filler material. Thanks tandem torch finishs CLOOS robotic welding cell weldment about 13 minutes faster (welding time), which is about $18 \%$ increasing welding productivity. Supposed higher weld qualityappearance to twoaxis positioner was confirmed, as well even uniform weld penetration and smaller thermal affected zone thanks to tandem torch. Thanks off-line laser sensor is weld positioning and compensates tolerated dimensions andrising deformationduring welding single seams on weldment.

General annual yield on all robotic welding cells is around 7940 pieces (of all types), which in case of pillar listed in experiment about 203 pieces per year. Therefore for the present one modernized CLOOS welding cell weld pillars several working shiftsand after it is used on other weldments. In annual yield it responding on the average two piecesof pillar per working shift.In light of time savings takes welding on IGM robotic welding cell 72 minutes and on CLOOS robotic welding cell 59 minutes. It is savings about 13 minutes (18\%) all welding time. Be necessary bear st. in mind, that the over all advanced of robotic welding, stays henceforth most important factor practice of robot operator. Only experienced welding operator will garrant maximum productivity and alsoweld quality attainable on welding robotic cell.

\section{ACKNOWLEDGMENTS}

Acknowledgements belongs to cooperative company Agrostroj Pelhrimov, where were realized own robotic welding and also VUT FSI Brno, where were realized experiment.

\section{REFERENCES}

[Agrostroj2018]Firemnívideoprezentace. In: Http://www.agrostroj.cz [online]. Pelhřimov:Created by AVT design, 2017 [cit. 2018-02-17]. Availablefrom: http://www.agrostroj.cz/cz/novinky/5a3279764c0cf-firemnivideoprezentace.

[CLOOS 2018] Cloos robotic welding. In: Robotic and

Automation [online]. 2018 [cit. 2018-02-20].

Available

from:https://roboticsandautomationnews.com/2017/10/20/clo os-and-baumu\%CC\%88ller-find-increased-efficiency-inautomated-welding-technology/14633/.

[CLOOS 2018] Tandem Weld. Cloos [online]. Deutschland: Carl CloosSchweisstechnik, 2018 [cit. 2018-04-10].

[OUDEN 2009] OUDEN, Gertden a Marcel Joseph Marie HERMANS. Welding technology. Delft: VSSD, 2009. ISBN 978906562205-1.

Availablefrom:

$\mathrm{cz} /$ procesy/details/tandem-weld/ https://www.cloos.de/de- 
CONTACT

Ing. Marian Sigmund, Ph.D.

FSI VUT Brno, Faculty of Mechanical Engineering,

Institute of Welding and Surface Threatment,

Technicka 2896/2, Brno 616 69, Brno, Czech Republic

+420 54114 2611, sigmund@fme.vutbr.cz 